\title{
MAQASID AL-SHARIAH PHILOSOPHY IN MONETARY REGIME TOWARDS INCLUSIVE SUSTAINABLE GROWTH
}

\author{
Mohd Noor Omar \\ Institute of Islamic Understanding, Malaysia \\ Email: mnoor@ikim.gov.my \\ Norhanim Mat Sari \\ Putra Business School, Malaysia \\ Email: norhanim@putrabs.edu.my
}

\begin{abstract}
This paper studies on the Maqasid al-Shariah philosophy with the aim establish an appropriate Islamic monetary regime in achieving the aspiration of Shariah that promote inclusive and sustainable growth of the ecosystem.From the analysis, this study shows that Islamic monetary mechanism and instruments as well as Islamic financial institutions (IFIs) operations are still exposed to the practice that are prohibited in Islam and also influenced by monetary policy tools and transmission channels set by the Central Bank. The study supports and affirms the establishment of an Islamic monetary system that transmits the monetary policy through channels with interest free and risk sharing Islamic instruments. For that, an equitable distribution of wealth for social Islamic justice as well as a balance inclusive and sustainable economic well-being would be attained.
\end{abstract}

Keywords: Maqasid al-Shariah; Islamic monetary system; Islamic economics, Finance and banking; Central Bank.

\section{A. Introduction}

Having made the Maqasid al-Shariah as a benchmark to fulfilling the objectives of Islamic teaching, the study of monetary regime in Islamic finance emanating from Maqasid al-Shariah is particularly important to ensure inclusive and sustainable growth in the economy. Theoretically in the academic, governments create money and central bank controls monetary policy. However, that is not always the case in practice. Many studies have shown that most money currently in existence is created by the private banks, through the process of creating financial product based on interest. The production of interest based debt is intimately linked to the money creation in the modern financial system (Zaman, 2015).

Given its vital association with all the Islamic sciences, the concept of Maqasid al-Shariah has turned into an authentic structure for creating theories, models, approaches and plans of change in different parts of life. Vitally, financial improvement has likewise gotten some Maqasid-based intercessions as of late, a standout amongst the most imperative of this being Chapra's (2008) work. Two essential inquiries should be tended to with respect to the implications of the Maqasid on monetary discourse and particularly in accordance with financial improvement; what part can the Maqasid play in understanding financial issues, breaking down financial marvels and figuring financial strategies? What significance does the concept of Maqasid have in the investigation of financial advancement in the Islamic point of view? 
This paper covers on the structure of monetary system from the conventional perspective related to its objective, roles of central bank and monetary policy tools and monetary transmission mechanism. The theory of Maqasid al-Shariahis elaborated with its concept, essence and the relationship between Maqasid al-Shariah and the monetary system in arriving at the Maqasid alShariah framework.

\section{A.1. Research Methodology}

This paper is subjective and theoretical in nature. The researcher conducts the substance examination technique by readings the past writings and written works identified with the topic. This study applies both the inductive and deductive strategies and also the scientific technique to look at and investigate the applicable literary works and build up the connection amongst Maslahah(benefit) and Shariah outcome with the standard structure of framework assessment (systematic inquiry).Hence, this study utilises the content analysis method into the monetary regime respectively to the objective of the law (Maqasid al-Shariah).The characterizations of monetary system and instruments are evaluated peculiar to the essence of maslahah and the downside of the mafsadah(mischief).

\section{B. Literature Review: The Philosophy of Maqasid Al-Shariah}

The term Maqasidal-Shariah is a compound word framed from two words, "maqāsid" (sing. maqsid or maqsad) and al-Shariah. The word "maqsid" in the Arabic wordlist implies reason, goal or shrewdness. The second word, "alShariah" in its limited use alludes to the Islamic Law. Al-Raysuni (2013) states that "What is implied by Maqasid al-Shariah is its motivation or objective, and the basic reasons which the Lawgiver includes put inside each of its decisions". Ibn Ashur (2013) presents what can be depicted as a far-reaching meaning of Maqasid al-Shariah. He says that the Islamic legislation's general purpose comprise of more profound implications and internal parts of knowledge considered by the Lawgiver in all or the greater part of the areas and conditions of enactment. They are not kept to a specific sort of the Shariah orders. Accordingly, they incorporate the general attributes of the Shariah, its broadly useful and whatever ideas thought about by the legislation. They incorporate certain implications and thoughts that are available in many of the Shariah command. Subsequent reviewing different meanings of the term, including those given by IbnAshur and al-Raysuni characterizes Maqasid al-Shariah as basically "the reasons which the law was set up to satisfy for the benefit of humankind".

The proposition of Maqasid al-Shariahhas been developed over hundreds of years from negligible scattered explanations of the $u s u l$ al-figh books to a specific, well-structured theory of Islamic jurisprudence. The fundamental insight and aims of Shariah references were frequently made in usul al-fighworks since from the time of Imam al-Shafi'i who is the organizer of the art of usul al-figh until the contemporary time. The theory of Maqasid al-Shariah and its definition was made known during the season of Abu al-Ma'ali al-Juwaini (d.476 AH).Al-Juwaini expounded on a basic five fundamental necessities. Then, Abu-Hamid al-Ghazali (d.505 AH) revamped, and systemised them respectively (Al-Yubi, $1433 \mathrm{AH}$ ). 
Through inductive examining of the directions of the Qur'an and Sunnah, scholars deducted that there are shrewd purposes in every ruling of the Shariah and it can be summed up in two reasons; magnetising benefit, and guard from impairment of humankind. It is in accordance with this that Ibn al-Qayyim (2009) states that: "The Shariah is based on the founding of intelligence and individuals' welfare in this world and the hereafter. It is about equity, benevolence, prosperity and insight."

\section{Analysis: Maqasid al-Shariah and Monetary Regime}

There are different motivations to keep up that the Maqasid al-Shariah are vital to all financial examination, particularly as they identify with the subject of deprivation, possessions transference and monetary improvement. As observed above, in every one of discourse concerning the Maqasid al-Shariah, all researchers, legal scholars and jurist, from the time of al-Juwaini $(476 \mathrm{AH})$ and followed by al-Ghazali (d.505 AH), are consistent on the way that safeguarding and distribution of possessions is among the major goals of the Shariah close by the security of religion, life, offspring and astuteness. Islam considers asset to be a vital element for human survival on earth (Qur'an 4:5). Possessions remains as a focal prerequisite for the satisfaction of a number of the central commitments of Islam.

The whole targets of the Shariah can be summed up in the statement "the accomplishment of benefits (maslahah) and the aversion of mischief (mafsadah)" (Al-Raysuni, 2013). In the financial consciousness, what the Shariah stands is to dispense with all types of monetary improprieties, for example, poverty, unemployment, underemployment among people and to escalate the accessible assets for the general public in order to attain a sustainable living. The Shariah predisposition required to favour financial environment that would ensure the achievement of the prosperity of mankind in harmless manner.

The motive of Shariah in connection to economic dispersion and the accountability insuring justice for all individuals. It is to safeguards and prevents any type of deceiving, misrepresentation and injustice in financial dealings. Taking into the picture of riba and gambling correspondingly endorses some financial dues and benefits in the expense of all individuals unreasonably. As Quraishi \& Kamali (2000) states that the Shariah supports real economic activity and mutual agreement in trade purposely to empower a person to gain an appropriate living, and guarantee the flow stream of business commerce. The Shariah has allowed every genuine mechanism and procedures that are required for development and enhanced success to individuals. Any abusive activities that can obstructing to human thriving have been announced unlawful. Monetary advancement with the respect with lawful and fair procedures in managing financial and asset is essential for the improvement of human life basically connected to the Maqasid.

Chapra(2009) presents that the goals (Maqasid) of the Islamic monetary application are a) financial prosperity within the framework of the ethical standards; b) fraternity and equity inclusion; c) just and fair pay; and d) flexibility, equality and social welfare. Faridi (1983), referred to in Mohammad \& Shahwan (2013), presents that the objectives of the Islamic monetary framework are equity and value; arrangement of the financial needs of the people or 
financial wellbeing; improvement of the people's monetary assets or financial development; and change in the social milieu of the community.

The re-emergence of Islamic economics, finance and banking for the past three decades, has driven scholars to advance an inclusive hypothetical structure of modern Islamic monetary economics (Uddin, 2016). There is an obvious different between the Islamic concept of finance and the conventional finance. Islamic finance is a combination of two words; finance reflects the financial system currently practiced and by adding Islamic, make it provisional to something that governs the whole life and the fate of life in hereafter prescribed by the Islamic teaching. However, the dilemma is Islamic finance, throughout the current practice observed to be deviated from what is propounded by Islamic concept and spirit supposedly for instance efficiency and fairness; rather emphasis to mere label mechanics. In Islam, the Shariah law is constructed on the basis of wisdom and human wellbeing in this world and hereafter (maslahah fi aldunyawa al-akhirah). It is all about fairness, compassion, welfare and prudence. Anything diverges from fairness to tyranny, from kindness to disservice, from happiness to despair and from wisdom to imprudence, is not in accordance with the Shariah framework(Lamido, 2016). Indeed, Maqasid al-Shariah as the higher objective of the shariah is the best approach to test on the Islamicity of monetary system and firmly cannot depart from something claimed to be Islamic.

There must be a practice that portray significantly a nexus of moral value in the legal context (Zakariyah, 2015). Dusuki \& Abozaid (2007), Ahmed(2011), Al-Mubarak \& Osmani(2010), Eddy Yusof et al., (2009) Jalil(2006) Laldin \& Furqani(2013) Soualhi(2015) Vejzagic \& Smolo(2011) and Yazid \& Asmadi(2015) highlighted on the important of the vital element of Maqasid al-Shariahin Islamic finance. What more in assessing a clear divinity prohibition in Islamic finance from practicing usurious (riba-based) activities (Abdul-Rahman (2011), Ahmad \& Hassan (2007), Amuda(2015), M Umer Chapra (2006) Fairooz \& Khir(2012), Farooq (2009); Fathurrahman (2012), Islahi (2012), Kahf (2006),Kula (2008), Saeed (1996) and Thomas(2006). The practice of Islamic finance expressively departs from its philosophy (Siddiqi, 2006). Thus far, Islamic finance has yet to fully substituted the conventional system. According to (Ariff, 2014), "Islamic banking is still under the tail of conventional banking, not only with products that are extremely similar to those offered by conventional banks, but also with conventional banks having a strong manifestation as stakeholders in the Islamic banking industry".

The roles and functions of money are the main substances in this misconception. Money in Islam is observed as a medium of exchange and unit of measure (Ismail \& Tohirin, 2010). (Usmani, 2010)pointed that money is a means to achieve definite objectives because it is not the objective itself. Money in itself has no inherent utility. Therefore, money cannot be deliberated as capital $(\mathrm{M} \neq$ $\mathrm{K})$; which is consistently associated with the risk component in a business. Money also cannot be restrained as a commodity (or asset) $(\mathrm{M} \neq \mathrm{C})$ to permit tradability as it is just a consideration in the deal even if the form of money is commodity money such as gold, silver even other valuable commodity. Money needs to be combined into capital by legal arrangement if the motivation of money transacted for profit making. It should also assume the risk inherent with the project/property) $\mathrm{M}+\mathrm{L} \rightarrow \mathrm{K}$ (Toutounchian, 2006). Furthermore, it must be substituted to a commodity/asset in order to assume the intrinsic utility 
transformation function.

Money is a fundamental subject in economics for the functioning of financial system. From the Islamic perspective, money is for medium of trade and custom for economic value measurement. Money is an abstract that cannot be traded or something that is likely to produce yields without economic undertakings. The divine quotation on the anomaly between trade and riba is clearly need to be enlighten. If money is intended to be traded with money, the Islamic ruling on ribāwi (usurious) transaction need to be observed(Omar, 2011). As what being claimed by the Quran in verse 2; 275 , even immediately after the verse read, the moral obligation to be adhered trade and riba transaction. Islam taught that such a ribāwi deal must take place with the situation that it is on spot basis (hand to hand) and for an equivalent amount (Sahih Muslim, hadith no. 3854) (Al-Hajjaj \& Siddiqui, 2009). Within the context of conventional system, money and financial transactions traded money with money on a deferred basis, and the repayment of loaned money with an extra money over the loaned amount is put into practise(Anwar, 2003).

Toutounchian (2002) contended that when money is transformed into some form of capital or investing funds, any profit is legitimised or otherwise it is just 'money producing money'. Thus, he solidified as the spirit of lending with interest, referring to the difference between interest as a charge for money and a profit as a return from investment of capital. Khan and Mirakhor, (1994) assert: "It is an error of modern theory to treat interest as the price of, or return for capital. Money is not capital, not even representative of capital. It is only potential capital which requires the service of the entrepreneur to transform the potentiality into reality; the lender has nothing to do with the transformation of money into capital and with using it productively" (Shaukat \& Alhabshi, 2015). The substance of money therefore is a value in the instinctively social convention in the form of a thing that are valuable, portability, durability, divisibility, considerably limited in supply and uniformity but inseparable from its physical or numerical form.

\section{Discussion:}

\section{D.1. Institutional Roles and Monetary Policy}

The purposes of the Central Bank are to ensure financial stability, execution of provident policy of liquidity, smooth running of payment and settlement systems and as a lender of last resort (Bank of International Settlements, 2014). The Central Bank also sets the interest rate level that allows banks to limit their debt level in the interbank money market. This exercise is to avoid insolvency crisis and to ensure the smooth operational of the payment system (Ponsot \& Rossi, 2009). The Central Bank performing the lender of last resort in the event of emergency conditions, in which the Central Bank will lend out as ample as needed of money to ensure the banks to meet their cash commitments to their depositors.

Central bank uses the interest rates, open market operations, reserve requirement, discount window lending, and currency board as monetary policy tools. The monetary authority will alleviate price by increasing or decreasing the interest rate to control or inflate the money supply. If the interest rates are higher it will boost savings and deter borrowing; and if the interest rates are lower, it 
will invite investment borrowing. Both of these effects can either lessen or inflate the growth of the money supply.

There are four main monetary transmission channels: (i)the interest rate channel-can be utilized for expansionary as well as contractionary policy. It can influence investment, property price and consumer expenditures;(ii) the asset price channel-in an expansion monetary policy will require to higher equity prices which may cause investment more attractive. Higher equity prices will also lead to upsurge wealth, increases spending and increases aggregate demand; (iii) the exchange rate channel-affect both supply and demand aggregate;(iv) the monetary and credit channel. The classical monetarist view is that money either narrow money or broad money aggregates regulate the price of assets, goods and its relation with long run inflation. While Bernanke\& Gertler (1995) believes that credit channel could effect on price and output level (Loayza \& Schmidt-Hebbel, 2002).

Studies by Meltzer (1969, 1970, 2001), Brunner and Meltzer (1972, 1988, 1990), Dotsey and Otrok (1994), McCallum (1990, 1999, 2001, 2004), Christiano and Rostagno (2001) Nelson (2003a, 2003b) and McCallum and Nelson (2004) show that money channel secures a significant role in the monetary policy transmission (Kassim et. al. 2009). Credit channel is related to the bank balance sheet and supply of loan by the intermediaries like commercial banks, merchant banks, finance companies and other private institutions that provide credits. Empirical studies by Friedman $(1968,1984)$, Bernanke \& Blinder (1988), Gertler \& Gilchrist (1993), Kashyap \& Stein (1995), Bernanke \& Gertler (1995), Walsh \& Wilcox (1995), Garretsen \& Swank (2003), Kakes, (1998), (Iacoviello \& Minetti, 2008), Paligorova \& Sierra (2012), Hall (2001), Iacoviello \& Minetti (2008), Oliner \& Rudebusch (1996), Altunbas, Gambacorta \& Marques-Ibanez (2010), Disyatat (2011), Icks \& Ricks (2010), Jiménez, Ongena, Peydró, \& Saurina, (2012), Aysun, Brady, \& Honig (2013), Montes \& Peixoto (2014) and, Orlowski (2015), highlight the function of the banking sector in monetary policy transmission process (Kassim\& Abdulla, 2006). A similar study features the macroeconomic variables such as interest rate, inflation, unemployment, and output that have an impact of turmoil in the banking sector(Kassim\& Majid, 2009:39).

Some analyses have been done to categorize the relationship between money supply and output, interest rates and prices/inflation. However, the argument is still inadequate where some researchers like Thornton \& Batten (1985), (King, 1986), Mankiw, Romer, \& Weil (1992), Sims, (2013) stated that there was an impact of the money supply on output, interest rate and prices. Provisionally others like Fiege and Pearce (1979), Sims (1980b),Diaz-Alejandro (1985), Geweke (1986), Friedman \& Kuttner (1993) proposed that money was neutral (Tan\& Baharumshah, 1999). In a nutshell, the monetary policy can be spread to various channels and it is also open to many challenges such as fluctuations in the global economy, environment, exchange rate depreciation, fall of the commodities prices, changes in the capital and shock beyond a control of the central bank.

\section{D.2. Deliberation of Islamic Monetary System}

Most Fuqaha agree that the bank interest rate is equivalent to riba. Therefore, scholars believe that Islamic economics can be achieved by removing 
interest rates from the conventional economy. Islamic banks acquire four main characteristics; risk sharing; asset backed or asset based; no exploitation; and financing of non-sinful activity (El-Hawaryet al., 2004). In-terms of risk sharing, Islamic banks centre upon profit and loss sharing as opposed to conventional banks that uphold interest rates (Ariff, 1989).

Nonetheless Islamic banking is a modern concept, and therefore removing interest rates from modern Islamic banking is not an easy task, as Islamic banks are based on the conventional banking model which is governed by the conventional national monetary policy where interest rates are the main mechanism to control the money supply and inflation. Hence, the modern Islamic banks have no other choice but to benchmark against the interest rates of the conventional banks to compete in the market.

The effects of benchmarking include the high cost of funds incurred by the Islamic banks. Even though most of the Islamic banks' products are Shariah compliant, the true spirit of Islamic finance cannot be achieved because the Islamic banks' profit rates follow the rates of the conventional banks (Chapra, 1985). It is also important to stress that many Muslim scholars agree that riba is not only related to increased (double or multiple) amounts of money charged by the lender, but whether the amount charged is justifiable as long as the transaction shall not contain the elements of exploitation, oppression, unfairness and uncertainty (Azahari, 2009). In practice, however, Islamic banks' reference to riba is justified on the grounds that they are relatively new, compared to conventional banks which have already been in operation for more than 200 years.

This, as mentioned, brings up the existential question as to whether an Islamic bank is similar to a conventional bank. In substantiating this question, Khan (2010) states that Islamic banks, despite being in operation for more than three decades, are still far from their ideals; a condition, which Asutay (2007; 2012) terms 'social failure of Islamic banking'. The modern Muslim scholars who contributed to the discussion on monetary policy in Islam include Siddiqi (1981), Kahf (1981, 2006), Chapra (1981, 1985, 1990, 1995), Uzair (1990), Choudhury (1997, 2005, 2009), Choudhry \& Mirakhor (1997), Anjum (2007), Toutounchian (2004, 2006, 2009),Yusof, Wosabi, \& Majid (2009), Sukmana\& Kassim (2010), Ismal (2010, 2011, 2013), Mat Sari \& Mirakhor (2012), Zaheer (2012), Leith, Moldovan, \& Rossi (2012), Rama (2013), Izadi \& Izadi (2013), Ergeç\&Arslan (2013), Putriani (2014), Z. Hasan (2008, 2011, 2016), Muhammad, Ab Rahman, \& Azam Sulaiman (2014), Ariff (2014), Uddin \& Halim (2015), Zaman(2015), Caporale, Çatık, Helmi, Ali, \& Tajik, (2016), Awad \& Soliman (2016), Hossain (2016), Al-Jarhi (1981, 2002, 2013, 2016), Uddin (2016), (Ahmad \& Ismail, 2017) and (Yunus, 2018).

According to Chapra (1990) and Ahmad (2008), the functions and roles of the Central Banks in Islamic economics are similar to the conventional system, adhere to the fractional reserve system as well as credit creation. Choudhry\& Mirakhor (1997) proposed using the equity-based government securities as the indirect instruments of monetary control with imposition of the bank credit ceiling, and statutory liquidity ratios. In addition, Toutounchian (2009) suggested the integration of money and banking based on Islamic principles into the capitalism system by using legal combination (such as contract of sales) to enable of integrating money into capital. In 2012, Mat Sari \&Mirakhor proposed equity premium based on risk sharing instruments to substitute interest rate for 
monetary policy in Malaysia. While Hasan (2016), suggested Leverage Control Rate (LCR) as a proxy of PLS. This can be possibly filling the gap addressed earlier by Al-Jarhi(2013). The suggestion was not to make major structural changes or infrastructural changes or to reform the conventional system but to provide an alternative of Shariah compliance monetary policy framework for Malaysia (Mat Sari \& Mirakhor, 2012). Nevertheless, it may be practical in the banking system but may not be applicable for non-bank financial institutions. The question still unreciprocated on how to tackle source of interest i.e. the fractional reserve that enable banks to create and multiplying money in the system. In the event of proposed Islamic system be implemented, fractional reserve remains even after the Islamization of the financial system. Ahmad \& Ismail (2017) analysed that full reserve system with the support from Quran and Hadith conceals the injustice and riba' hence achieving the Maqasid Shariah.

Contemporary scholars deliberated on the interest free banking system including modifications of the functions of the Central Banks in the Islamic economics. However, the practice still within the existing conventional structure of the commercial banks and the Central Bank in the capitalist system. Approaches in the Islamization of the banking and financial system done by replicating of the existing instruments of the conventional system monetary policy. The concept and application were still within the framework of the conventional banking system. Most of the contemporary Islamic scholars recommended some modifications to the existing structure because their understanding on the meaning and impression of the monetary policy covered the roles, functions, tools and instruments of the Central Banks.

\section{D.3. Maqasid al-Shariah based monetary regime}

The piecemeal approach of Islamising and mimicking the conventional banks' products and services has not only proven far from reaching social justice and developmentalism in an aspirational sense, but has highlighted the fact that Islamic banks are closely following conventional banks in their operations by providing more loans and financing by utilizing sales principals of Islamic finance rather than asset-based profit-loss-sharing instruments. The creation of more loans and debts contributes to the spread of interest rates in the banking system. Since the amount of debt created in the bank is more than the money supply in the system, it may lead to a crisis during a downturn in the economy, because there will be default in payment due to less currency in circulation compared to the amount of debt.

One of the major hindrances to operate 'Islamically' is that the Islamic banks are subjected to the same monetary system of the conventional framework. The principal policy is governed by the conventional monetary system and managed by bankers with a conventional mentality. One recommendation or measure that may help to increase the value of Islamic banks in becoming more Islamic is that it needs to have its own Islamic monetary policy where interest rates should not be the main instrument or mechanism in transmitting the policy. Accordingly, the calculation of the Islamic banks' profit needs to be based on the market rates. This requires entirely a different mind-set, which aims to consider Islamic political economy as a system, rather than Islamic banking as an option. This study suggests that in a dual banking system it should have a twofold 
system, where if there is a conventional and Islamic bank then it should have an Islamic monetary policy for the Islamic banks. In Malaysia, except for the absence of Islamic monetary policy, there is almost a complete setup for the Islamic banking industry, which includes an Islamic money market and Islamic capital market. In this industry, the objective of the Islamic banking system is to remove riba, maisir and ghararin the transaction. However, if the main policy governing Islamic banks is based on interest rates, it is difficult to expect Islamic banks to achieve the objective of Maqasid al-shari'ah.

Islamic banks should remove all controversial contracts or products such as al-bay al-inah, tawarruq and al-bay al-dayn. By allowing al-bay al-dayn contract and implementing a fictitious system in awarding tawarruq contracts and al-bay alinah contracts, it is not only tarnishing the image of Islamic banking, but Islamic finance and Islam as a religion. The Shari'ah scholars should not allow tricks (hilah) or legal stratagem (hiyar) to justify the means.

The determination of the profit based on the cost of funds for the Islamic bank should not include rates of interest or benchmark against conventional banks' interest rates. Even though there is a lack of discussion about Islamic monetary system, it should not be limited to the activity of the central banks and the commercial banks. The broader context of Islamic monetary system should include not only the commercial sector (tijari) but also the social sector (ijtimai). Furthermore, without eliminating the elements of riba, gharar and maysir, and mobilizing Islamic fiscal instruments such as zakah, waqf and sadaqah along other institutions, Islamic monetary system will not able to achieve justice (al-'adalah) in terms of distribution of wealth in the society. Most modern Muslim scholars believe that the banking system is the best platform to apply the principles of Islamic finance and expect to achieve justice by modifying the financing terms and contracts of the conventional banks for example profit rate or rate of return.

As mentioned earlier, the objective of the Islamic monetary policy aims at achieving social justice in conducting financing and loans. Therefore, Islamic banks should provide financing for development projects and should also consider productive sectors in their financing rather than mainly focusing on financial sectors and real estate sectors. Islamic banks also shall consider financing project that are environmentally friendly and contributes to sustainable development. Applying the Islamic instrument is no longer the issue. Many of the conventional monetary instruments are also Islamic and some need modification. As outlined by Chapra (1985) that one of the objectives of Islamic monetary policy is to ensure equal distribution of wealth. However, current monetary policy system unable to do that and it requires implementation of prudent fiscal policies. Hence, it is important to stress that justice cannot be achieved by establishing more Islamic banks. Some scholars suggest that Islamic banks need to be more responsible and 'Islamic' by applying the true concept of corporate social responsibility (CSR) to close such gap. The proposal is by combining the functions of a social or ethical bank with Islamic banks within the banking framework thereby inclusive and sustainable growth would be able to materialised.

By becoming truly Islamic, then the Islamic bank automatically become exceedingly ethical and serve the community as a whole rather than only obliging to the shareholders. The recent implementation of the Value-Based intermediation in the case of Malaysian banking system has marked an 
important milestone for future Islamic banking to follow through.

\section{E. Conclusion}

In conclusion, justice in society will be established by the elimination of riba in the financial system; it cannot be achieved merely by changing the term 'interest rates' to profit rates and through 'Islamization' of conventional bank products and services. Furthermore, an Islamic economic system cannot be attained by establishing only 'Islamic banks' but it can be realized in a society that aims to provide a general system of Islamic political economy and achieves homo-Islamicus at a personal level. It is high time to establish an Islamic monetary policy where its function is not limited to transmitting the monetary policy through various channels by using Islamic instruments but also to ensure that equal distribution of wealth by transmitting the policy to the right channels and complimented with prudent fiscal policies by the government. The value of Islamic banks can only be upheld with the spirit of Maqasid al-Shariah through the Islamic monetary policy where the real rate of return should be the benchmark for the instrument and mechanism in transmitting the policy signal. A wider context of Islamic monetary system should embrace both the commercial sector (tijari) as well as the social sector (ijtima'i) for inclusive growth. The elements of riba, gharar and maysir shall be eliminated from the system consistent with the Shariah rulings. In achieving justice (al-'adalah) in terms of distribution of wealth in the society, instruments such as waqf and sadaqah can be revolutionised as a new mechanism for the financial and investment inclusion.

\section{Bibliography}

Abdul-Rahman, Y. (2011). The Art of Islamic Banking and Finance: Tools and Techniques for Community-Based Banking. The Art of Islamic Banking and Finance: Tools and Techniques for Community-Based Banking. https:// doi.org/10.1002/9781118258217

Ahmad, A. U. F., \& Hassan, M. K. (2007). Riba and Islamic Banking. Journal of Islamic Economics, Banking and Finance, 3, 1-33.

Ahmad, M. (2008). The Effect of Financial Deregulation on Money Demand in Malaysia. Munich Personal RePEc Archive, (42295). https:// doi.org/10.1227/01.NEU.0000349921.14519.2A

Ahmad, Z., \& Ismail, abdul G. (2017). Full reserve system and the Maqasid Shariah, 5(2), 58-66.

Ahmed, H. (2011). Maqasid Al-Shariah and Islamic Financial Products: A Framework for Assessment. ISRA International Journal of Islamic Finance, 3(1), 149-160. https:/ / doi.org/10.1142/9789812569394_0005

Al-Hajjaj, M. ibn, \& Siddiqui, T. A. al-H. (2009). Sahih Muslim.

Al-Jarhi, M. (2013). Gaps in the Theory and Practive of Islamic Economics, (41193). https://doi.org/10.5897/JAERD12.088

Al-Mubarak, T., \& Osmani, N. M. (2010). Applications of Maqasid al-Shari'ah and Maslahah in Islamic Banking. In International Seminar on Islamic Finance (pp. 1-10). https:// doi.org/10.13140/RG.2.1.3578.0644

Al-Raysuni, A. (2013). Imam Al-Shatibi's Theory of the Hihger Objectives and Intents of Islamic Law. The International Institute of Islamic Thought (Vol. 22). https://doi.org/10.1007/s13398-014-0173-7.2 
Altunbas, Y., Gambacorta, L., \& Marques-Ibanez, D. (2010). Bank risk and monetary policy. Journal of Financial Stability, 6, 121-129. https:// doi.org/10.1016/j.jfs.2009.07.001

Amuda, Y. J. (2015). CURRENT ISSUES IN ISLAMIC BANKING AND FINANCE. International Journal of Economics, Commerce and Management, III (4), 1-15.

Anwar M. (2003). Islamicity of Islamic Banking.Pdf. Arab Law Quarterly. Retrieved from http://www.jstor.org/stable/3382068

Ariff, M. (2014). Whither Islamic Banking? The World Economy, 733-746. https://doi.org/10.1111/twec.12171

Ashur, M. A.-T. I. (2013). Treatise on Maqasid al-Shariah. (T. by M. E.-T. El-Mesawi, Ed.), Book (Vol. 1). London: The International Institute of Islamic Thought. https:/ / doi.org/10.1017/CBO9781107415324.004

Awad, I. L., \& Soliman, A. M. (2016). The stability of the demand for money function in Islamic and non-Islamic monetary policy regimes, 21, 67-85.

Aysun, U., Brady, R., \& Honig, A. (2013). Financial frictions and the strength of monetary transmission. Journal of International Money and Finance, 32, 10971119. https:// doi.org/10.1016/j.jimonfin.2012.09.003

Bank of International Settlements. (2014). Re-thinking the Lender of Last Resort. BIS Papers. Retrieved from http://www.bis.org/publ/bppdf/bispap79.pdf

Bernanke, B. S., \& Blinder, A. S. (1988). Credit, money, and aggregate demand. American Economic Review, 78(2), 435-439. https://doi.org/10.1016/S01972510(11)70055-9

Bernanke, B. S., \& Gertler, M. (1995). Inside the Black Box: The Credit Channel of Monetary Policy Transmission. Journal of Economic Perspectives, 9(4), 27-48. https:// doi.org/10.1257/jep.9.4.27

Caporale, G. M., Çatık, A. N., Helmi, M. H., Ali, F. M., \& Tajik, M. (2016). The Bank Lending Channel in a Dual Banking System: Evidence from Malaysia. SSRN Working Paper.

Chapra, M Umer. (2006). The nature of riba in Islam. The Journal of Islamic $\begin{array}{llll}\text { Economics and } & \text { Finance, }\end{array}$ https:// doi.org/10.1017/CBO9781107415324.004

Chapra, M Umer, Bank, I. D., Clark-Murphy, M., Gerrans, P., \& Speelman, C. (2009). Vision of Development in the Light of Maqāsid Al-Sharī ‘ ah. Journal of Family and Economic Issues, 30(1), 4-19. https://doi.org/10.1007/s10834008-9133-8

Chapra, Muhammad Umer. (1990). Towards a Just Monetary System. JKAU: Islamic Econ (Vol. 2). Retrieved from http:/ / ierc.sbu.ac.ir/

Choudhry, N., \& Mirakhor, A. (1997). Indirect Instruments of Monetary Control in an Islamic Financial System. Islamic Economic Studies, 4(2). Retrieved from

http://www.irti.org/irj/go/km/docs/documents/IDBDevelopments/Int ernet/English/IRTI/CM/downloads/IES_Articles/Vol 4-2..Nurun Choudhry and A Mirakhor..INDIRECT INSTRUMENTS OF MONETARY..dp.pdf

Choudhury, M. A., Hussain, M. M. M. M., Alam Choudhury, M., \& Hussain, M. M. M. M. (2005). A paradigm of Islamic money and banking. International Journal of Social Economics, 32(3), 203-217. https:/ / doi.org/10.1108/03068290510580760 
Diaz-Alejandro, C. (1985). Good-bye financial repression, hello financial crash. Journal of Development Economics, 19(1-2), 1-24. https:// doi.org/10.1016/0304-3878(85)90036-7

Disyatat, P. (2011). The bank lending channel revisited. Journal of Money, Credit and Banking, 43(4), 711-734.

Dusuki, A. W., \& Abozaid, A. (2007). A Critical Appraisal On The Challenges Of Realizing Maqasid Al-Shariaah In Islamic Banking And Finance. IIUM Journal of Economics and Management, 15(2), 999-1000. https:// doi.org/10.2307/1236148

Eddy Yusof, Ezry Fahmy, Kashoogie, Jhordy, Anwar Kamal, Asim, ... Kam. (2009). Islamic Finance: Debt Versus Equity Financing in the Light of Maqasid Al-Shari'ah. Munich Personal RePEc Archive, 1-20. https:// doi.org/10.5897/JAERD12.088

Fairooz, M., \& Khir, A. (2012). The concept of the time value of money: a Shari' ah viewpoint. Isra Research Paper, 3(38), 1-52.

Farooq, M. O. (2009). The Riba-Interest Equation and Islam : Reexamination of the Traditional Arguments. Finance, 6, 99-111. https:/ / doi.org/10.2139/ssrn.1579324

Fathurrahman, A. (2012). Fractional Reserve Banking: Sebuah Representasi Ekonomi Semu ( Tinjauan Ekonomi Islam). La_Riba Jurnal Ekonomi Islam, VI(2), 179-197.

Friedman, B. M., \& Kuttner, K. N. (1993). Economic Activity and the Short-term Credit Markets: An Analysis of Prices and Quantities. Brookings Papers on Economic Activity, (2), 193-283. https://doi.org/10.2307/2534567

Friedman, M. (1968). The Role of Monetary Policy. In The American Economic Review (pp. 311-322). Retrieved from http:/ / search.ebscohost.com/login.aspx?direct=true\&db=eoh\&AN=00301 $54 \&$ site $=$ ehost-live $\&$ scope $=$ cite

Garretsen, H., \& Swank, J. (2003). The Bank Lending Channel in the Netherlands: The Impact of Monetary Policy on Households and Firms. De Economist, 151(1), 35-51. https:/ / doi.org/10.1023/ A:1022984614506

Gertler, M., \& Gilchrist, S. (1993). The Role of Credit Market Imperfections in the Monetary Transmission Mechanism: Arguments and Evidence. The Scandinavian Journal of Economics, 95(1), 43. https:// doi.org/10.2307/3440134

Geweke, J. (1986). Exact inference in the inequality constrained normal linear regression model. Journal of Applied Econometrics, 1(2), 127-141. https:// doi.org/10.1002/jae.3950010203

Hall, S. (2001). Credit channel effects in the monetary transmission mechanism. Bank of England Quarterly Bulletin, (1), 442-448.

Hasan, Z. (2016). PLS Finance and Monetary Policy : A New Measure Mooted, (2015), 288-297.

Iacoviello, M., \& Minetti, R. (2008). The credit channel of monetary policy: Evidence from the housing market. Journal of Macroeconomics, 30, 69-96. https:// doi.org/10.1016/j.jmacro.2006.12.001

Icks, M. O. R., \& Ricks, M. (2010). Regulating Money Creation after the Crisis. Harvard Business Law Review, 1(June), 75-142.

Islahi, A. A. (2001). An Analytical Study of al-Ghazali's Thought on Money and Interest. In The International Conference on al-Gazali's Legacy: Its Contemporary 
Relevance. Kuala Lumpur: International Institute of Islamic Thought and Civilization. Retrieved from http://mpra.ub.unimuenchen.de/41438/1/MPRA_paper_41438.pdf

Ismail, A. G. b., \& Tohirin, A. (2010). Islamic law and finance. Humanomics. https:// doi.org/10.1108/08288661011074954

Ismal, R. (2013). The Islamic Gracious Monetary Instruments: a Theoretical Approach. Journal of Economic and Administrative Sciences, 29(1), 63-80. https:/ / doi.org/10.1108/10264111311319231

Izadi, H. R., \& Izadi, M. (2013). New Monetary Policies in Usury Free Banking. Asian Economic and Financial Review, 3(7), 881-905.

Jalil, A. (2006). The Significances of Maslahah Concept and Doctrine of Maqasid ( Objectives ) Al-Shari 'Ah in Project Evaluation. The Journal of Muamalat and Islamic Finance Research, 3(1), 171-202.

Jiménez, G., Ongena, S., Peydró, J. L., \& Saurina, J. (2012). Credit supply and monetary policy: Identifying the bank balance-sheet channel with loan applications. American Economic Review, 102, 2301-2326. https:// doi.org/10.1257/aer.102.5.2301

Kahf, M. (2006). Maqasid al-Shari'ah in the Prohibition of Riba and Their Implication for Modern Islamic Finance. IIUM International Conference on Maqasid Al-Shari'ah, 184-203.

Kakes, J. (1998). Monetary transmission and business cycle asymmetry, (September), 1-28.

Kashyap, A. K., \& Stein, J. C. (1995). The impact of monetary policy on bank balance sheets. Carnegie-Rochester Conference Series on Public Policy, 42, 151195. https://doi.org/10.1016/0167-2231(95)00032-U

Kassim, N. M., \& Abdulla, A. K. M. A. (2006). The influence of attraction on internet banking: an extension to the trust-relationship commitment model. International Journal of Bank Marketing, 24(6), 424-442. https:// doi.org/10.1108/02652320610701744

Kassim, S. H., Shabri, M., Majid, A., \& Yusof, R. M. (2009). Impact of monetary policy shocks on the conventional and islamic banks in a dual banking system: Evidence from malaysia. Journal of Economic Cooperation and Development, 30(1), 41-58.

Kassim, S., \& Majid, M. S. (2009). The role of bank loans and deposits in the monetary transmission mechanism in Malaysia. International Journal of Banking and Finance, 6(2), pp.37-59.

King, S. R. (1986). Monetary Transmission: Through Bank Loans or Bank Liabilities? Journal of Money, Credit and Banking, 18(3), 290. https:/ / doi.org/10.2307/1992382

Kula, E. (2008). Is contemporary interest rate in conflict with Islamic ethics? Kyklos, 61(1), 45-64. https:/ / doi.org/10.1111/j.1467-6435.2008.00392.x

Laldin, M. A., \& Furqani, H. (2013). Developing Islamic finance in the framework of maqasid al-Shariah: Understanding the ends maqasid and the means. International Journal of Islamic and Middle Eastern Finance and Management, 6(4), 278-289. Retrieved from http://www.emeraldinsight.com/10.1108/IMEFM-05-2013-0057

Lamido, A. A. (2016). Maqasid al-Shari'ah as a framework for economic development theorization. International Journal of Islamic Economics and Finance Studies, 2(1), 27-49. 
Leith, C., Moldovan, I., \& Rossi, R. (2012). Optimal monetary policy in a New Keynesian model with habits in consumption. Review of Economic Dynamics, 15(3), 416-435. https:// doi.org/10.1016/j.red.2012.03.001

Loayza, N., \& Schmidt-Hebbel, K. (2002). Monetary policy functions and transmission mechanisms: an overview. Monetary Policy: Rules and Transmission Mechanisms, 1-20. Retrieved from http:// siteresources.worldbank.org/DEC/Resources/Monetary_Policy_O verview.pdf

Mankiw, N. . G., Romer, D., \& Weil, D. N. (1992). A Contribution to the Empirics of Economic Growth. The Quarterly Journal of Economics, 107(2), 407-437.

Mcleay, B. M., Radia, A., \& Thomas, R. (2014). Money in the modern economy: an introduction. Bank of England Quarterly Bulletin, 54(1), 4-13.

Mohammad, M. O., \& Shahwan, S. (2013). The Objective of Islamic Economic and Islamic Banking in Light of Maqasid Al-Shariah: A Critical Review. MiddleEast Journal of Scientific Research, 13 (Resear, 75-84. https:// doi.org/10.5829/idosi.mejsr.2013.13.1885

Montes, G. C., \& Peixoto, G. B. T. (2014). Risk-taking channel, bank lending channel and the "paradox of credibility": Evidence from Brazil. Economic Modelling, 39, 82-94. https:// doi.org/10.1016/j.econmod.2014.02.023

Oliner, S. D., \& Rudebusch, G. D. (1996). Is There a Broad Credit Channel for Monetary Po 1 i cy? FRBSF Economic Review, 1996, 1-13.

Omar, M. N. (2011). The Islamic View on Money and Its Implication to Financial Instruments. ISRA International Journal of Islamic Finance, 3(1), 161-168.

Orlowski, L. T. (2015). Monetary Expansion and Bank Credit : A Lack of Spark.

Paligorova, T., \& Sierra, J. (2012). Monetary policy and the risk-taking channel: Insights from the lending behaviour of banks. Bank of Canada Review, 23-30. Retrieved from http://ideas.repec.org/a/bca/bcarev/v2012y2012iautumn12p23-30.html

Ponsot, J.-F., \& Rossi, S. (2009). The Political Economy of Monetary Circuits. Hampshire: Macmilan Publishers Limited. https:// doi.org/10.1057/9780230245723

Putriani, D. (2014). A Critical Review on Interest Rate as A Tool of Monetary Policy. Tazkia Islamic Finance and Business Review, 9(2), 150-165. Retrieved from http://www.tifbr-tazkia.org/index.php/TIFBR/article/view/93

Quraishi, A., \& Kamali, M. H. (2000). Principles of Islamic Jurisprudence. Journal of Law and Religion, 15(1/2), 385. https:/ / doi.org/10.2307/1051529

Rahman Faridi, F. (1983). Theory of Fiscal Policy in an Islamic State. Journal of King Abdulaziz University: Islamic Economics, 1(1), 15-30.

Rama, A. (2013). Monetary Dynamics and Commodity Money: A Discussion in the Context of a Fiat Money vs Commodity Money. Esensi, 4(1), 30-43.

Razmi, F., Mohamed, A., Chin, L., \& Habibullah, M. S. (2015). The effects of oil price and US economy on Thailand's macroeconomy: The role of monetary transmission mechanism. International Journal of Economics and Management, 9(SpecialIssue), 121-141. https://doi.org/10.5897/JAERD12.088

Saeed, A. (1996). Islamic Banking and Interest : A Study of the Prohibition of Riba And its Contemporary Interpretation. Journal of King Abdulaziz UniversityIslamic Economics, 2, 71-75. https://doi.org/10.4197/islec.17-2.8

Sari, N., \& Mirakhor, A. (2012). Islamic Monetary Policy in Malaysia: A Conceptual Framework. 2nd ISRA Colloquium 2012, (November), 1-22. 
Retrieved from http://ifikr.isra.my/documents/10180/16168/e1Norhanim Islamic Monetory Policy.pdf

Shaukat, M., \& Alhabshi, O. (2015). Instability of Interest Bearing Debt FInance and the Islamic Finance Alternative. Islamic Economics Studies, 23(2).

Shaukat, M., Hasan, Z., Syed, D., Alhabshi, O., Shaukat, M., Mirakhor, A., \& Lumpur, K. (2013). Instability of Interest Bearing Debt Finance and The Islamic Finance Alternative.

Siddiqi, M. N. (2006). Islamic Banking and Finance in Theory and Practice: A Survey of State of the Art. Islamic Economic Studies, 13, 1-48. https:// doi.org/10.4197/islec.17-1.4

Sims, E. (2013). What Measure of Output Should be Targeted in Interest Rate Rules?*.

Soualhi, Y. (2015). Application of shariah contracts in contemporary Islamic finance: A maqasid perspective. Intellectual Discourse.

Sukmana, R., \& Kassim, S. H. (2010). Roles of the Islamic banks in the monetary transmission process in Malaysia. International Journal of Islamic and Middle Eastern Finance and Management. https:// doi.org/10.1108/17538391011033834

Tan, H. B., \& Baharumshah, A. Z. (1999). Dynamic causal chain of money, output, interest rate and prices in Malaysia: evidence based on vector errorcorrection modelling analysis. International Economic Journal, 13(1), 103-120. https:/ / doi.org/10.1080/10168739900000032

Thomas, A. (2006). Interest in Islamic Economics: Unterstanding Riba. https:// doi.org/10.1093/jis/et1068

Thornton, D. L., \& Batten, D. S. (1985). Lag-Length Selection and Tests of Granger Causality Between Money and Income. Journal of Money, Credit and Banking, 17(2), 164. https:// doi.org/10.2307/1992331

Toutounchian, I. (2004). Islamic Banking: A last Ditch to Save Capitalism, (February), 1-25.

Toutounchian, I. (2006). Integrating Money in Capital Theory: A Legal Perspective (Islamic Finance). ... for Islamic Economics and the Islamic ..., 75$113 . \quad$ Retrieved from http://www.toutounchian.com/Articles/My_paper_Harvard_Univ.pdf\%5 Cnhttp://toutounchian.com/presentations/Paper presented at Harvard's Seventh Forum on Islamic Economics 2006.pdf

Toutounchian, I. (2009). Islamic Money and Banking: Integrating Money in Capital Theory. Singapore: John Wiley \& Sons, Inc.

Uddin, M. A. (2016). Reemergence of Islamic Monetary Economics: A Review of Theory and Practice. Munich Personal RePEc Achive, Paper No. 72081.

Uddin, M. A., \& Halim, A. (2015). Islamic monetary policy: Is there an alternative of interest rate, (67697).

Usmani, M. T. (2010). Post-crisis reforms: Some points to ponder. Retrieved from http://www.iefpedia.com/english/wpcontent/uploads/2010/02/UsmaniPostCrisisReforms.pdf

Vejzagic, M., \& Smolo, E. (2011). Maqasid Al-Shariah in Islamic Finance: An Overview. In 4th Islamic Economic Sytem Conference (pp. 1-22). https:// doi.org/10.1017/CBO9781107415324.004

Walsh, C. E., \& Wilcox, J. A. (1995). Bank Credit and Economic Activity.

Yazid, M., \& Asmadi, M. N. (2015). The Practices of Islamic Finance in Upholding 
the Islamic Values and the Maqasid Shariah. International Review of Management and Business Research, 4(1), 2306-9007.

Yunus, N. S. M. (2018). Value Based Intermediation: Beyond Profit. Global Islamic Finance Forum 2018 (GIFF 2018).

Yusof, R. M., Wosabi, M. Al, \& Majid, M. S. A. (2009). Monetary policy shocks and Islamic banks' deposits in a dual banking system: Empirical evidence from Malaysia and Bahrain. Journal of Economic Cooperation and Development, $30,1-26$.

Zakariyah, L. (2015). Harmonising Legality With Morality in Islamic Banking and Finance: A Quest for Maqāșid al- Sharī'ah Paradigm. Intellectual Discourse, 23(Special Issue), 355-376.

Zaman, A. (2015). On the Nature of Modern Money. In 10th International Conference on Islamic Economics \& Finance. Doha, Qatar. 